\title{
The Fiscal Position of the State and Local Government Sector: Developments in the 1990s
}

Laura S. Rubin, of the Board's Division of Research and Statistics, prepared this article. Jeff Campione and Robin McKnight provided research assistance.

After difficulties during the early 1990s, the fiscal position of state and local governments has improved considerably in the past three years. States, as a group, have fared relatively well, although some local governments are still struggling with fiscal difficulties. In addition, the sector as a whole continues to face persistent underlying structural problems. This article first examines the primary budget concepts that are generally used to evaluate the fiscal condition of state and local governments. Next it surveys the status of the various levels of government, that is, states, cities, counties, and school districts. Then it discusses some of the underlying problems in state and local budgeting, particularly in the areas of health care, education, corrections, and pensions.

\section{BUDGET CONCEPTS}

The national income and product accounts (NIPA), published by the Commerce Department, provide a comprehensive summary of the receipts and expenditures of all state and local governments and their enterprises. Up-to-date NIPA information for the state governments and the local governments separately is not available, although social insurance fund data for the sector are published and will be discussed later. According to the NIPA, the fiscal position of state and local governments, excluding their social insurance funds, has improved in recent years: Although the surplus of current accounts dipped markedly in 1990, it then trended up for several years and remained about unchanged over 1994 and 1995. A similar pattern is apparent for the surplus as a share of GDP, but more broadly, when measured this way, the surplus has been on a general downward trend for the past quarter-century (chart 1).

The examination of data published by a variety of state and local organizations provides some insight into how the various levels of government are faring. These sources focus on the general fund budgets, which are the primary accounts for financing day-today operations of both state and local governments. In every state except Vermont, the general fund and many other budget accounts are required to be balanced, either within each fiscal year or over a twoyear period. The accompanying box discusses state balanced-budget requirements and the ways states meet them.

The general fund accounts of state governments exclude earmarked funds, federal funds, and pension funds. They also exclude most outlays for capital investment. As a result, the general fund accounts of all state and local governments cover only about half of the sector's spending, and therefore any reading of

1. State and local sector surplus, 1968-95

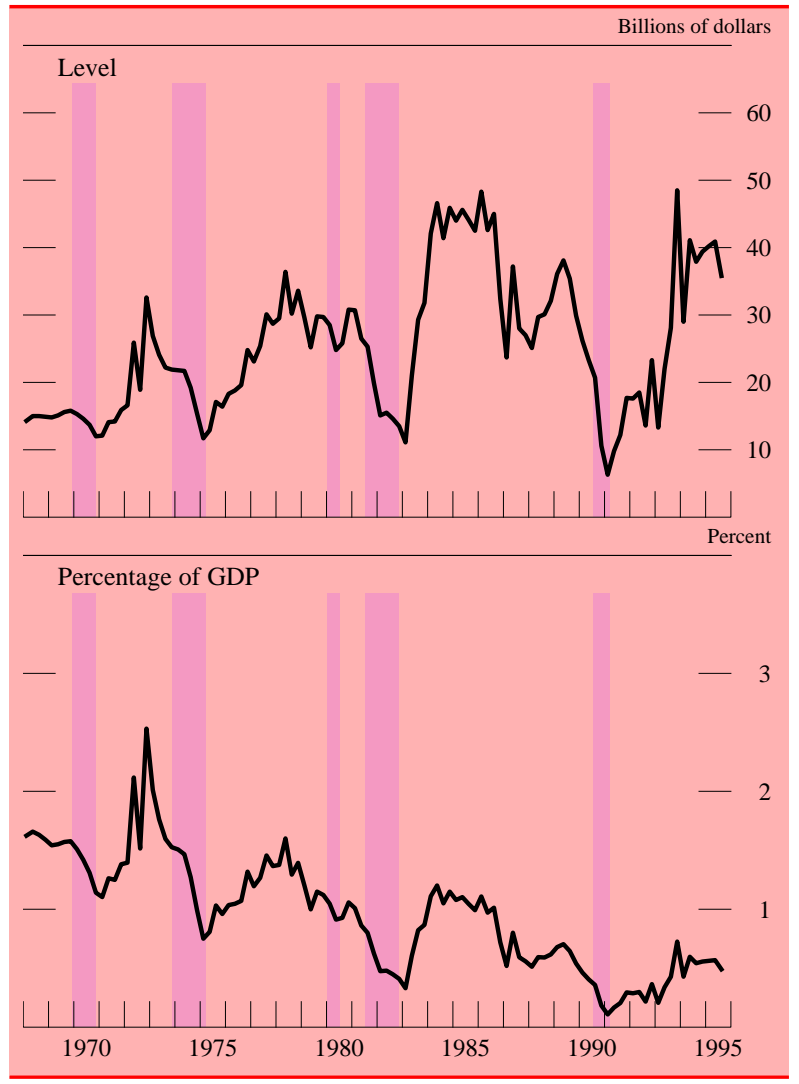

Note. Shaded areas indicate periods of recession as defined by the National Bureau of Economic Research. Data are quarterly and on a NIPA basis; they exclude social insurance funds; the figure for 1995 is through Q3. 
the fiscal position of a government based solely on its general fund budget is incomplete. However, data on the general fund accounts, particularly for states, are readily available and are viewed as a good indicator of state fiscal conditions. Although both the general fund accounts and the NIPA include interest outlays, only the NIPA includes the services of capital assets-equipment and structures—as expenditures. ${ }^{1}$

The general fund accounts of state and local governments may include revenues that are not counted in the NIPA but that could buoy, or mask, an other-

1. Until the revision to the NIPA, released in January 1996, the spending measure that determined the NIPA surplus or deficit for state and local governments included purchases of all durable goods and structures. However, the NIPA now feature a current account measure of the surplus or deficit. Thus, outlays for equipment, a component of durable goods, and structures have been reclassified as investment, and services of these assets, along with compensation and spending on other services, nondurable goods, and certain durable goods that are not capitalized, like parts, are being reported as current-account purchases or government consumption expenditures. wise tenuous budgetary picture. The following are examples of budgetary practices used by many states.

- States focus on a general funds measure that reflects their balance sheet position rather than the difference between revenues and outlays over a year. Thus, states whose current-year expenditures exceed their current-year revenues could still be reporting a positive year-end general fund "balance" as long as that gap does not exceed the net surpluses accumulated in previous years. For example, for fiscal year 1995, which ended June 30, 1995, the National Conference of State Legislators (NCSL) projected a closing balance of $\$ 4$ billion even though planned expenditures were expected to exceed revenues by more than $\$ 1$ billion. ${ }^{2}$

2. Corina L. Eckl, Karen Carter, and Arturo Perez, State Budget Actions 1994, National Conference of State Legislatures (November 1994), p. 42.

\section{State Requirements for Balanced Budgets}

The definition of "balance" used by state governments does not necessarily accord with the generally accepted view, say for individuals, that current revenues cover current expenditures. For state governments, a balanced general fund budget for a given fiscal year requires that revenues plus surpluses from preceding years be at least as large as outlays. Forty-nine states have balanced-budget requirements. They focus on general fund budgets, although, in many states, other state funds are also expected to balance. More states have constitutionally mandated balancedbudget requirements than statutory requirements. Generally, the governor must submit a balanced budget or the legislature must enact one. In some states the budget need not be in balance at the end of the fiscal year, whereas other states allow the carryover of a deficit into the next fiscal year if necessary.

If a shortfall in the general fund is anticipated during the planning stages of a budget, which occur during the legislative session preceding a given fiscal year, state governments usually cut spending or increase taxes, fees, and charges. In addition, many governments rely on interfund transfers, for example, from so-called rainy-day funds or from other funds, to ensure fiscal balance. Forty-five states have budget stabilization, or rainy-day, funds whose primary purpose is to provide revenue during periods of fiscal distress. ${ }^{1}$ In addition, some states transfer money from trust funds, which always have a large, positive balance. For example, funds

1. Revenues for the rainy-day funds are determined through appropriations or automatically as a function of a state's budget surplus. Only Arkansas, Hawaii, Illinois, Montana, and Oregon, along with the District of Columbia, do not have rainy-day funds. may be transferred from a state's education or transportation trust fund to the general fund near year-end and then transferred back shortly thereafter. Generally, these types of transfers do not involve pension funds.

Some states have also used proceeds of short-term debt offerings, and occasionally bonds, to cover shortfalls in their general fund accounts, thereby "balancing" those budgets. Other balancing techniques employed when shortfalls appear toward the end of the fiscal year include the postponement of payments until after the end of the year or, sometimes, the acceleration of some receipts into the year. Finally, certain functions may be moved outside the realm of the general fund budget. Thus, although a simple comparison of expected outlays and receipts from current sources may imply a deficit, considerable fiscal maneuvering can produce a "balance."

Analysts emphasize that state officials want and try to act responsibly to balance their budgets. Moreover, concern about a state's municipal bond rating may encourage actions to balance its budget. Therefore, even without explicit laws, the manifest intention of officials is to balance state and local budgets according to the terms and definitions described above, and the primary motivation for balanced budgets is not the formal requirement but rather "tradition, practice, and public expectation." 2 Wyoming is a case in point: Although the state is not legally required by constitution or statutory provision to balance its budget, the expectation is so strong that it is considered to have the requirement in practice.

2. Ron Snell, State Balanced Budget Requirements: Provisions and Practice, National Conference of State Legislatures, forthcoming. 
- Second, governments may count the proceeds of short-term debt offerings as a source of funds (revenue), although these are not included in the NIPA.

- Third, governments may transfer funds into their general fund from other accounts, or they may sell an asset. For example, in the period from fiscal 1991 to 1994, the State of New York sold more than \$300 million of assets to public authorities, which borrowed to finance the purchases. A transaction of this type increases revenue in the general fund but does not change the fiscal condition for the state on a NIPA basis.

\section{THE CURRENT FISCAL CONDITION OF STATES AND LOCAL GOVERNMENTS}

Like the NIPA, the general fund accounts of states and many local governments suggest significant improvement from weakness earlier in the 1990s. Expenditures for the sector are split about evenly between states and local governments. At the local government level, the share of expenditures is roughly one-third each for cities and school districts, with counties making up most of the remaining outlays. State revenues have come in above the expectations of state budget planners for the past few years, and year-end balances have grown to more than 5 percent of expenditures. For some local governments, general fund data are not available. However, even though the data sources are varied, the story is clear: Many local governments still appear to be struggling to improve their budgetary positions.

\section{States}

The fiscal position of most states has continued to improve. According to a recent survey by the
National Conference of State Legislatures (NCSL), general fund balances have risen from less than 1 percent of states' expenditures in fiscal 1992 to an estimated 5.1 percent in fiscal 1995 (chart 2). Indeed, the recent improvement compares favorably with the period from 1984 to 1990 when general fund balances averaged 4 percent of expenditures. Even so, while the improvement is nationwide, weakness is still apparent in a number of states.

In fiscal 1995, which ended last June for most state governments, tax collections were stronger than expected; as a result, budgets improved despite considerable growth in outlays and small legislated tax reductions. However, budget officers are expecting their fiscal stance to weaken a little in fiscal 1996 because they are expecting revenue growth to slow. According to a midyear survey of the 1996 fiscal situation by NCSL, forty states estimated that revenues would come in at or above target for the current fiscal year. But ten states were expecting revenues to be below projections, compared with just two states last year. Several of these states indicated that the weakness was due to smaller-than-expected sales and excise taxes, whereas a few states blamed weaker personal income tax collections. The states reporting problems were Idaho, Hawaii, Maine, Maryland, Nebraska, New Mexico, Rhode Island, South Dakota, Vermont, and Wyoming. On the spending side, most states indicated that expenditures were expected to end up close to planned levels, and fewer states than last year are expecting overruns.

The strengthening in fiscal positions since the early 1990s reflects several factors. Among these factors were tax hikes and spending restraint early in the decade and a slowing of the growth in outlays for Medicaid from the enormous advances seen early in the 1990s. Even so, Medicaid payments increased

\section{Indicators of the fiscal position of states}

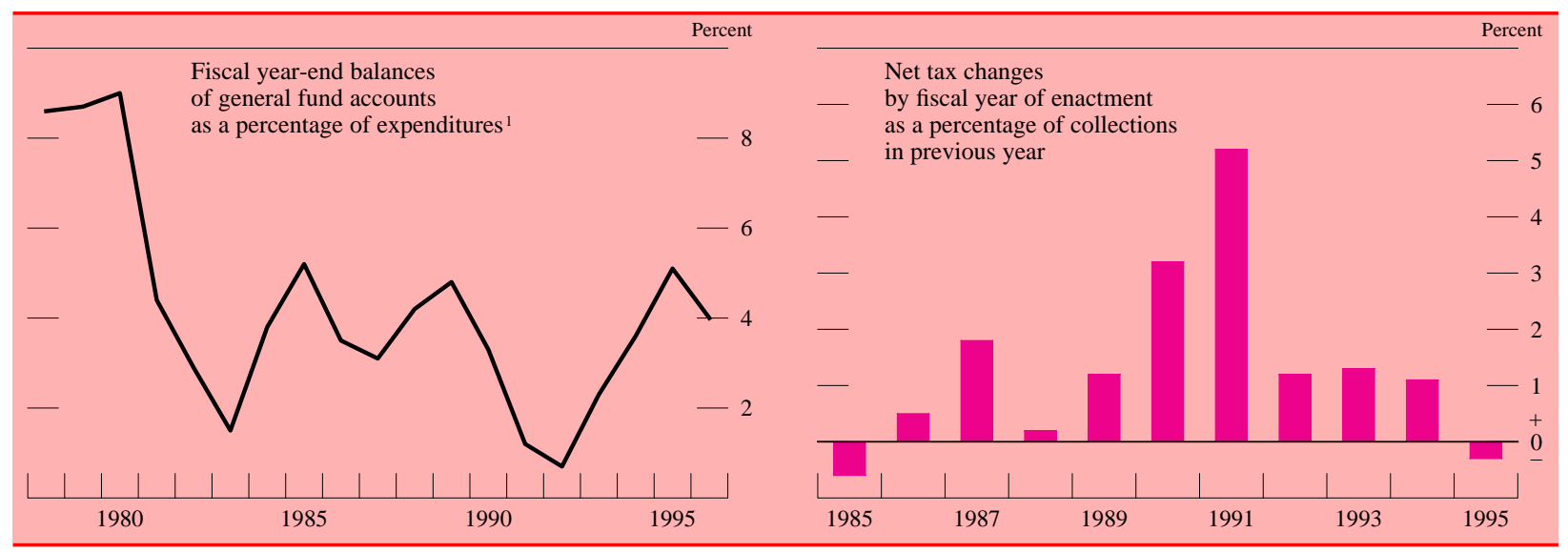

1. Annual data. Figure for 1995 is an estimate and for 1996, a forecast.

Source. National Conference of State Legislatures 
nearly 10 percent in each of the past two years, and they are expected to rise at about the same rate in fiscal 1996.

With the improvements in budget positions, many states have cut taxes in recent years. In 1995, many states cut the personal income tax, and some acted to reduce local property taxes. However, according to the Center for the Study of the States, "Few of the reductions were large enough to make a big difference in the income of taxpayers or the fiscal situation of the states." 3 States tend to raise taxes during or immediately after a recession to make up for shortfalls and then to hold the line or even cut taxes several years later when receipts are strong. The small tax reductions in fiscal 1995, like those in 1985, followed that general cyclical pattern (chart 2).

\section{Local Governments}

Although no comprehensive data sources on the current fiscal position of local governments are available, information from various sources indicates that the budgets of local governments as a group have not fared as well as those of states. According to the Census of Governments, which is available only through 1992, local governments experienced considerably more fiscal distress than states between the mid-1980s and 1992. Although local governments recorded deficits beginning in 1986, state governments were not in deficit until 1991. In addition, local government deficits were larger as a percentage of their expenditures than were state government deficits. Other data sources also substantiate the continuation of fiscal difficulties at the local government level.

\section{Cities}

According to survey data from the National League of Cities, the fiscal condition of cities improved considerably in 1993 and 1994. In fiscal 1995, however, more than half of large cities reporting were expecting to run deficits in their general fund accounts (chart 3). If, after final data are available, these deficits are substantiated, the percentage of cities with deficits in 1995 will be the largest since at least 1985. Fiscal 1994 turned out to be a better year than had been projected primarily because cities succeeded in holding down the growth of expenditures. Even so, in 1994, nearly 30 percent of cities were reporting defi-

3. Steven D. Gold, "1995 Tax Cuts: Widespread But Not Revolutionary,” State Fiscal Brief (December 1995), p. 1. cits. A more recent opinion survey indicates that in fiscal 1995 economic and fiscal conditions continued to improve; as a result, the budgetary position of many cities may turn out to have been better than expected earlier. The factors having the most negative effects on the fiscal position of cities included infrastructure needs and spending, unfunded federal and state mandates, city employee health benefits, and crime.

\section{Counties}

The National Association of Counties has been surveying counties for only a few years. In general, the survey reports suggest continuing fiscal weakness. According to the 1995 report, when counties were asked to describe their fiscal condition, less than 5 percent of respondents said that revenues were expanding and that they were able to undertake new programs. In contrast, more than 60 percent either

3. Indicators of the fiscal position of local governments, 1985-95

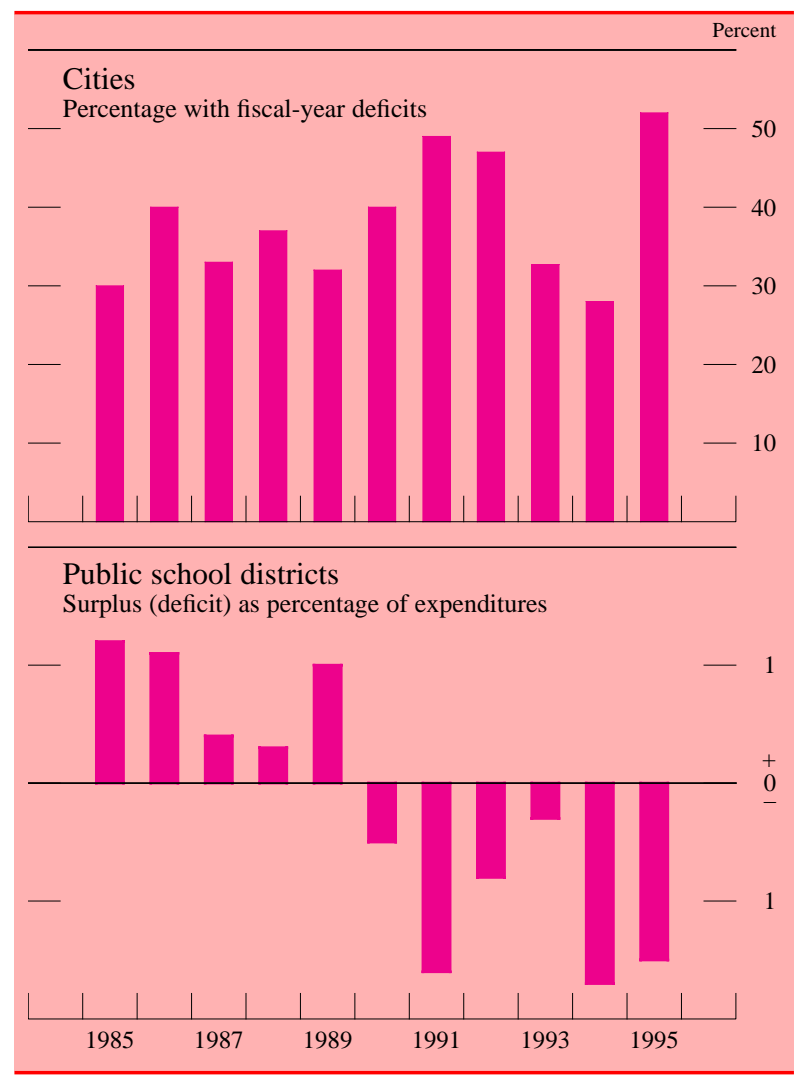

NotE. For cities, figure for 1995 is an estimate. For school districts, figures for 1994 and 1995 are estimates.

Sources. For cities, National League of Cities, City Fiscal Conditions in 1995, June 1995. For public school districts, National Education Association, 1994-95 Estimates of School Statistics, April 1995. 
were having difficulty maintaining services or were reducing discretionary programs, and 4 percent characterized their fiscal position as in crisis.

\section{School Districts}

Data from the National Education Association suggest that the fiscal condition of school districts appears no better than that of cities and counties. Public school districts, whose data include capital accounts, ran a surplus through the school year ending in 1989 and have been in deficit ever since (chart 3). The deficits reflect imbalances in operating accounts as well as a step-up in school construction early in the 1990s.

In summary, a number of local governments have continued to experience budgetary problems. The weakness probably is due partly to reductions in aid by state governments, especially in the early 1990s, as states tried to deal with their own fiscal distress. For example, the growth of state aid for public education slowed sharply beginning in 1991 (chart 4). However, after years of cutting aid to local governments, about half the states are planning to help local governments during fiscal 1996, particularly through increased school aid.

\section{CONTINUING PRESSURES}

Although the current situation looks more favorable for many governments, difficult problems may be looming on the horizon. Problems could arise from

4. State aid for public education $(\mathrm{K}-12)$ measured by the percentage change from year to year, 1986-95

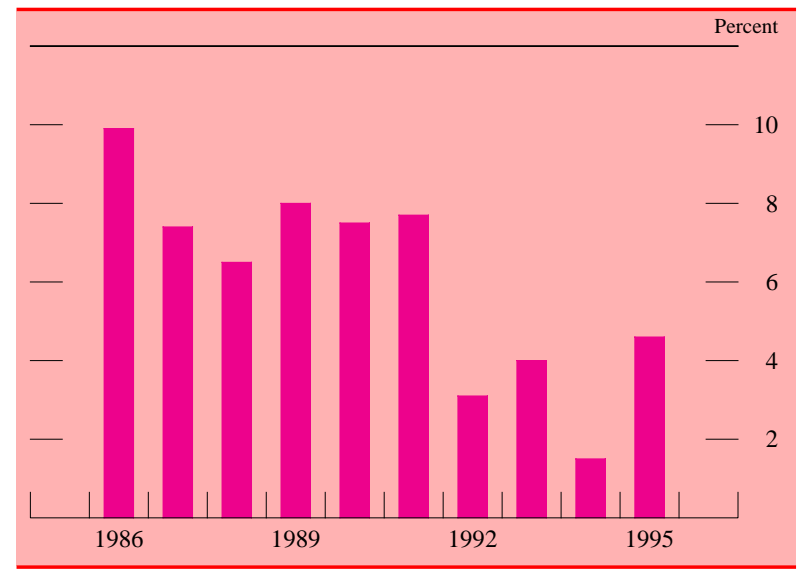

NoTE. Figures for 1994 and 1995 are estimates.

Source. National Education Association, 1994-95 Estimates of School Statistics, April 1995. political and economic events, such as reductions in federal aid or an economic downturn, as well as from the fundamental underlying changes in demand that have been stretching governments for the past decade. Three particular areas of concern-corrections, health, and education - reflect both demographic and social trends. In addition, with a considerable share of state and local pension plans underfunded, meeting payments for future retirees could add significantly to fiscal pressure. Finally, if legislation to reduce the federal budget deficit is enacted, it will likely entail reductions in aid to state and local governments.

\section{Corrections}

Though still a relatively small portion of total spending, corrections has been one of the fastest-growing programs of state and local governments in recent years. Spurred by rising crime rates and a growing awareness of and concern about safety, legislators have been eager to get tough on criminals. As a result, governments have been quick to adopt measures that set mandatory minimum sentences and to try juveniles as adults. Between 1993 and the end of 1995, twenty-four states had passed "three strikes and you're out" type of laws, which require mandatory sentences for habitual offenders.

Not surprisingly, the costs of the criminal justice system appear to be rising. In fiscal 1995, appropriations for corrections rose at least 10 percent in fourteen states. Funds were spent on hiring additional prosecutors and policemen, adding beds to existing facilities, and building new jails and prisons. The "three strikes" laws could prove particularly costly as they raise the need for prison capacity. Several states have estimated significant increases in state expenditures to build more prisons in the years ahead. In addition, some states anticipate additional court costs. For example, the California Judicial Council anticipates a rising number of felony jury trials. ${ }^{4}$ Defendants may be more willing to accept the risk of a trial and less willing to take a plea bargain that would result in a lengthy jail term.

The number of prison inmates rose dramatically between 1980 and 1995, with the number of state prisoners tripling to about 1 million in 1995 (chart 5). ${ }^{5}$ By comparison, the state prison population

4. Donna Lyons, 'Three Strikes'Legislation Update, National Conference of State Legislatures (December 1995).

5. In 1994, state facilities held 62 percent of incarcerated individuals, and jails under the jurisdictions of local governments held 33 percent; federal prisons held the remaining 6 percent. 
was essentially flat from 1930 to 1970 and rose only a little during the 1970s. The recent wave of anticrime legislation, including the "three strikes" laws, appears to be bolstering prison populations further. In 1995 , the number of prisoners under the jurisdiction of state authorities jumped 9.1 percent, compared with a gain of 7.2 percent, on average, during the preceding five years.

\section{Demand for state and local services, 1977-95}

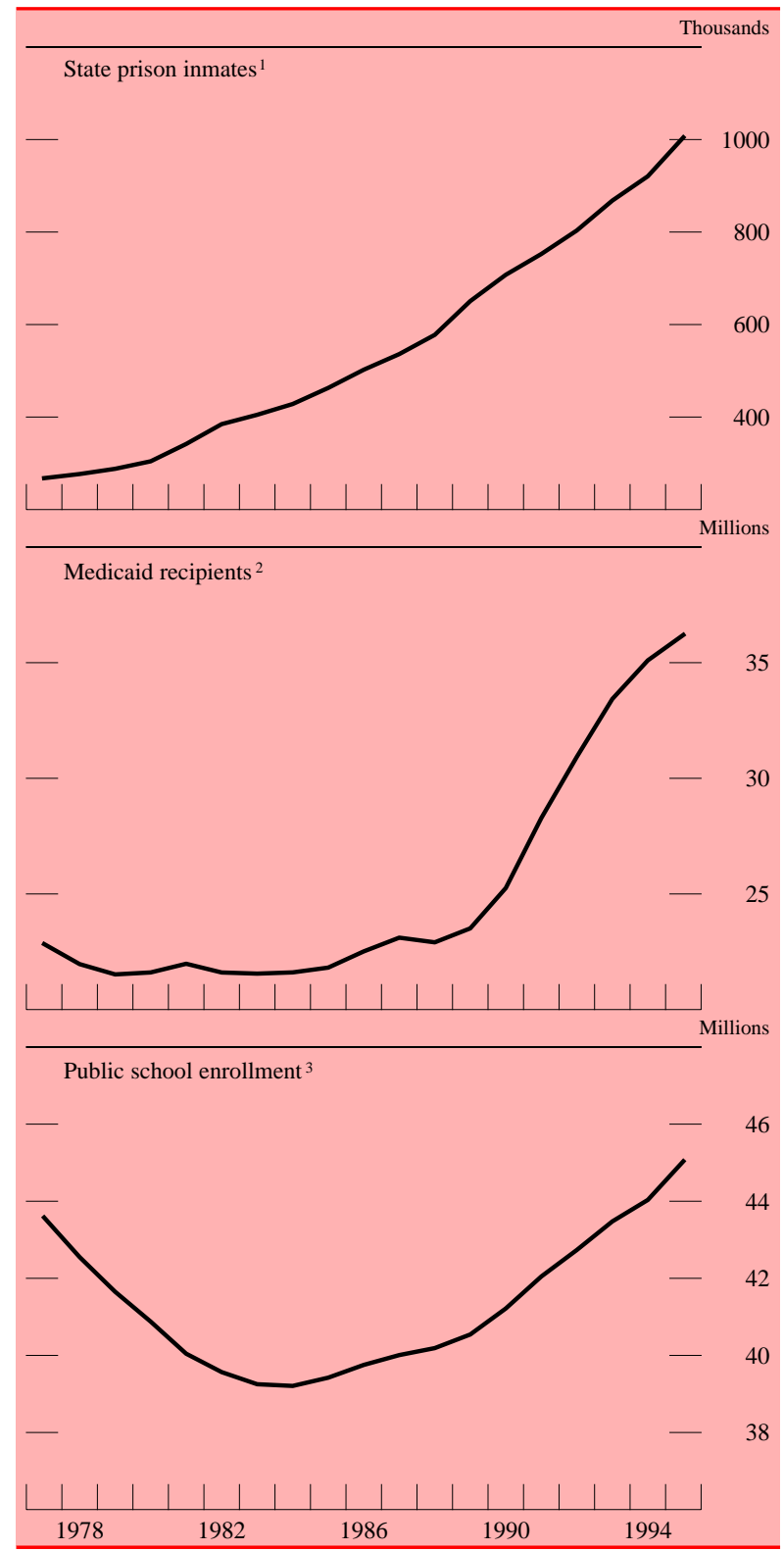

NoTE. Data are annual.

1. Annual data as of June 30 of each year.

2. Figure for 1995 is estimated by the Health Care Financing Administration. 3. Figures for 1994 and 1995 are estimates by the Department of Education. SourCES. Data for the number of state prison inmates are from the Department of Justice; for Medicaid recipients, the Health Care Financing Administration; for public school enrollment, the Department of Education.
The recent increases in prison populations reflect both more arrests and an increased likelihood of incarceration after arrest. These trends are associated with the increase in anti-crime measures and the rise of illegal drug use; notably, the percentage of prisoners serving sentences for drug-related charges rose from 6 percent to 22 percent during the past fifteen years. However, the good news is that the rate of violent crime came down a little in 1993 and 1994 and that the rate for property crime has fallen 9 percent since its high in 1991. These developments likely are improving the perception of public safety.

\section{Medicaid}

Medicaid provides specific medical services to most recipients of federal cash assistance programs (Aid to Families with Dependent Children and Supplemental Security Income) and to others meeting a separate test of financial need. States administer the program and, with the federal government, fund it. The programs vary considerably because states may choose to offer optional services that are not mandated and because their policies on reimbursement and administration differ. The federal match is a function of the per capita income of the particular state, and the federal government's share ranges from 50 percent to 78 percent.

Between 1988 and 1993, total transfer payments for Medicaid rose from 10 percent to more than 16 percent of state and local government expenditures. ${ }^{6}$ The increase reflected various factors including the recession, rising health care costs, a surge in the use of provider taxes, and the shift of many beneficiaries from state general assistance programs to Medicaid. ${ }^{7}$ The number of recipients also rose because federal mandates were expanded to require states to cover individuals at higher levels of income and to include previously optional services. In particular, coverage of pregnant women and children was significantly expanded primarily by raising the income limit below which families qualified and by extending the age limit for eligible children.

6. State and local transfer payments for Medicaid include the federal matching grant along with state and local government payments.

7. Early in the decade, many states accepted donations from or imposed taxes on health care providers, such as hospitals, in schemes to help bolster federal matching requirements for Medicaid. The term "provider taxes" includes these taxes, fees, and contributions. In recent years, the use of provider taxes has been muted by federal regulations. 
In recent years, the pressure on state budgets from Medicaid expenditures has waned as the economy has strengthened and the rise in health care costs has slowed. Moreover, most of the newly eligible individuals have now been added to the rolls. Notably, the growth of Medicaid recipients has slowed from a high of 12 percent in 1991 to just 3 percent in 1995 (chart 5). Correspondingly, the share of Medicaid spending has stabilized since 1993 as advances in state and local government expenditures on Medicaid have come down from the nearly 30 percent increase in 1991. Nevertheless, at a range of 8-9 percent, growth in Medicaid spending has remained high in recent years and is expected to exceed increases in most other state and local programs in the near term (chart 6).

\section{Education}

After a major push to upgrade public school systems in the 1970s and 1980s, many state and local governments reduced their efforts in the 1990s. Although state spending on education increased during the first half of the 1990s, states assigned higher priorities to other programs, particularly corrections and Medicaid, and the pace of growth of education spending lagged. As a result, state spending on education fell as a share of general fund spending from just under 50 percent in 1989 to less than 42 percent in 1995 , even as public school enrollment steadily increased (chart 5).

The increase in public education programs during the 1970s and 1980s added noticeably to costs. As a

6. Comparison of nominal government expenditures by program, 1988-95

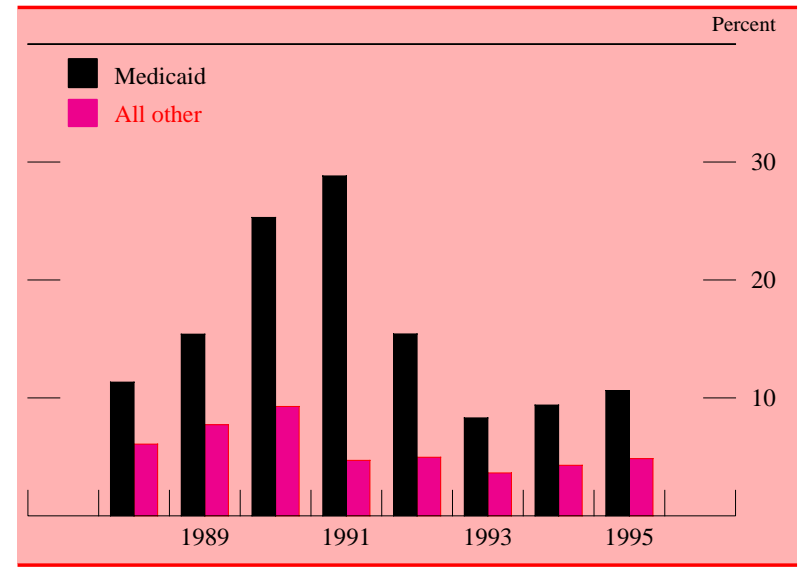

Note. Expenditures are measured as percentage changes from Q4 to Q4. Figures for 1995:Q4 are estimates by Federal Reserve Board staff members. SOURCE. NIPA. result of the Education of the Handicapped Act passed in 1975, proportionately more handicapped children were educated in the public school system. In addition, programs for gifted, learning-disabled, and bilingual children were expanded, all adding significantly to costs. Besides the increase in programs, some states adopted quality standards for their education systems, and these measures also helped to speed up growth in operational outlays.

Because of the reordering of priorities, in fiscal 1991 growth in actual K-12 spending - at less than half the pace of the previous year-fell far short of planned increases in appropriations, as states made midyear adjustments to spending plans with the goal of balancing their budgets. Again in 1994, growth in actual spending fell short of appropriations. On balance, states reduced the growth in aid to local public schools in the 1990s (chart 4). Higher education took an even bigger hit: Growth in appropriations fell in 1991 and 1992, and the level of appropriations actually declined slightly in fiscal 1993.

With the improvement in state budgets in recent years, some efforts are being made to make up for cuts earlier in the decade. For fiscal 1995, growth in actual spending rose about 8 percent for K-12 education, but based on appropriations, growth in outlays for education is likely to slow again in fiscal 1996. Growth in spending for higher education rose somewhat to nearly 4 percent in fiscal 1995 and is expected to remain at that pace in 1996. In addition, some states are working on plans to aid local governments in 1996. Nonetheless, the demographics are such that state and local governments will be facing a rising demand for public education. Annual increases in $\mathrm{K}-12$ enrollment in public schools are expected to hover in the 2 percent range through 1997 and then to rise more gradually over the next decade. Public elementary school enrollment is expected to peak in 2002, whereas enrollment in high schools is forecast to advance for several more years. As a result, governments may be forced to increase spending on education in the years ahead, even if they are not expanding programs.

\section{Pensions}

Another area of concern affecting state and local budgets is pensions. Many are considerably underfunded, and meeting pension obligations will add to fiscal pressure in the years ahead for many governments.

State and local public employee retirement systems (PERS), along with other social insurance systems, 
are included in the NIPA. Inflows to the insurance funds include contributions by employers and personnel as well as interest earnings. Offsetting these revenues are transfer payments to retirees and administrative expenses. Surpluses of state and local social insurance funds are a source of saving that is available each year to the rest of the economy through the credit and equity markets. Through the 1970s and 1980s the surpluses grew steadily on a NIPA basis; after peaking at $\$ 68$ billion in 1992, the surplus fell to $\$ 58$ billion in 1995 .

For the state and local sector as a whole, the retirement systems constitute approximately 90 percent of all the social insurance funds, which in some states also include workers' compensation and temporary disability insurance. Roughly 90 percent of the pension assets of all state and local government workers are held by about 10 percent of the approximately 6,000 pension funds in the sector. About 90 percent of state and local government employees are covered by defined benefit pension plans, and 9 percent of workers are covered by defined contribution plans. ${ }^{8}$ PERS alone control more than $\$ 1$ trillion in assets-nearly 30 percent of all pension assets.

Assets of PERS are invested mainly in U.S. government securities and in corporate stocks and bonds. State and local governments administer the retirement systems, and state and local laws govern the provision of retirement benefits and the protection of the plans' assets. In some cases the pension fund is the sole guarantor, and in others the employers, that is, the governments themselves, stand behind the systems. The Public Pension Coordinating Council (PPCC) provides information and helps coordinate activities of the pension administrators. ${ }^{9}$ Unlike private pension plans, however, PERS are not subject to the provisions of the Employee Retirement Income Security Act of 1974 (ERISA). ERISA provides standards for participation, vesting, funding, fiduciary duties, disclosure, and reporting and prescribes mechanisms to enforce these standards.

An important distinction exists between the corpus, or assets, of state and local pension trusts and the government's contributions. Although state and local governments have rarely borrowed from the corpus, they have, at times, altered their pension fund contributions in response to budgetary distress. Annual contributions depend on actuarial assumptions, one

8. State and local government employees have the option of participating in social security, but given the broad availability of the public employees retirement systems, most have chosen not to do so.

9. PPCC is conducting a survey to determine the proportion of those systems backed by the governments themselves. of which is the expected rate of return on pension fund investments. In the early 1990s, many states adopted unrealistically high rates of return, which allowed them to reduce their own contributions, thereby freeing up funds for general government purposes. Meanwhile, some states took other steps to help bolster the general fund. For example, California postponed normal employer contributions for fiscal 1994 until fiscal 1995, and Maine made the decision to spread the unfunded pension liability over more years. As a result, government contributions actually fell in real terms in the late 1980s and early 1990s. According to the Government Accounting Office, in 1991 only 80 percent of actuarially required annual contributions were being made.

Based on definitions applied by state and local governments, in the early 1990s total assets of PERS covered more than 80 percent of total liabilities, which are calculated to include current liabilities plus liabilities based on assumed future salary and service increases up to retirement. ${ }^{10}$ Governments expect to exist indefinitely and therefore include the stream of future benefits in this calculation. The ratio of assets to liabilities is referred to as the actuarial accrued liability funding ratio. By comparison, for private sector pension plans, the funding ratio omits liabilities accruing from future services.

The view of the PPCC is that PERS are fairly well funded and that plan participants are also protected by the laws of state and local governments. ${ }^{11}$ In 1975 , the funding level was just 51 percent. Then, spurred partly by concern about the prospect of being included under the terms of ERISA, state and local governments worked to increase the level of funding in the pension funds up to the 82 percent level in fiscal 1992. However, the funding status of public pension plans varies widely, and many plans are significantly underfunded, with funding ratios of less than 75 percent. In addition, the funding ratios may vary according to the type of plan. For example, proportionately more plans for police and firefighters are poorly funded compared with plans for general government employees (chart 7).

Data from the Bureau of Economic Analysis indicate that net inflows to state and local pension funds, in the aggregate, deteriorated between the late 1980s and 1995. The accumulated surpluses of these

10. Current liabilities are accrued benefits earned to date by workers and retirees based on years of service and salaries.

11. Some analysts argue that one can compare the pension funding ratio to a home mortgage; that is, if 80 percent of a home mortgage is paid off, with twenty to twenty-five years left on the mortgage, the mortgage holder is in good shape. 
accounts fund future pension liabilities, and the adequacy of these surpluses must be judged in relation to the growth of liabilities. Although a good measure of liabilities is not available, total wages and salaries is used as a very rough indicator. The surplus of the social insurance funds measured in relation to state and local employee wages and salaries rose steadily through the 1970s and leveled off in the 1980s. ${ }^{12}$ However, in recent years, the surplus has come down relative to payrolls (chart 8). Much of this decline can be explained by the weakness in real government contributions as previously noted; personal contributions by government workers trended up until 1994 and then flattened. Meanwhile, the growth in real benefits to annuitants appears to have accelerated. In addition, the ratio of active state and local workers to retirees is declining.

12. The charts show social insurance funds instead of retirement funds because the data are more readily available.

7. Distribution of state and local pension plans by funding ratio, fiscal year 1992

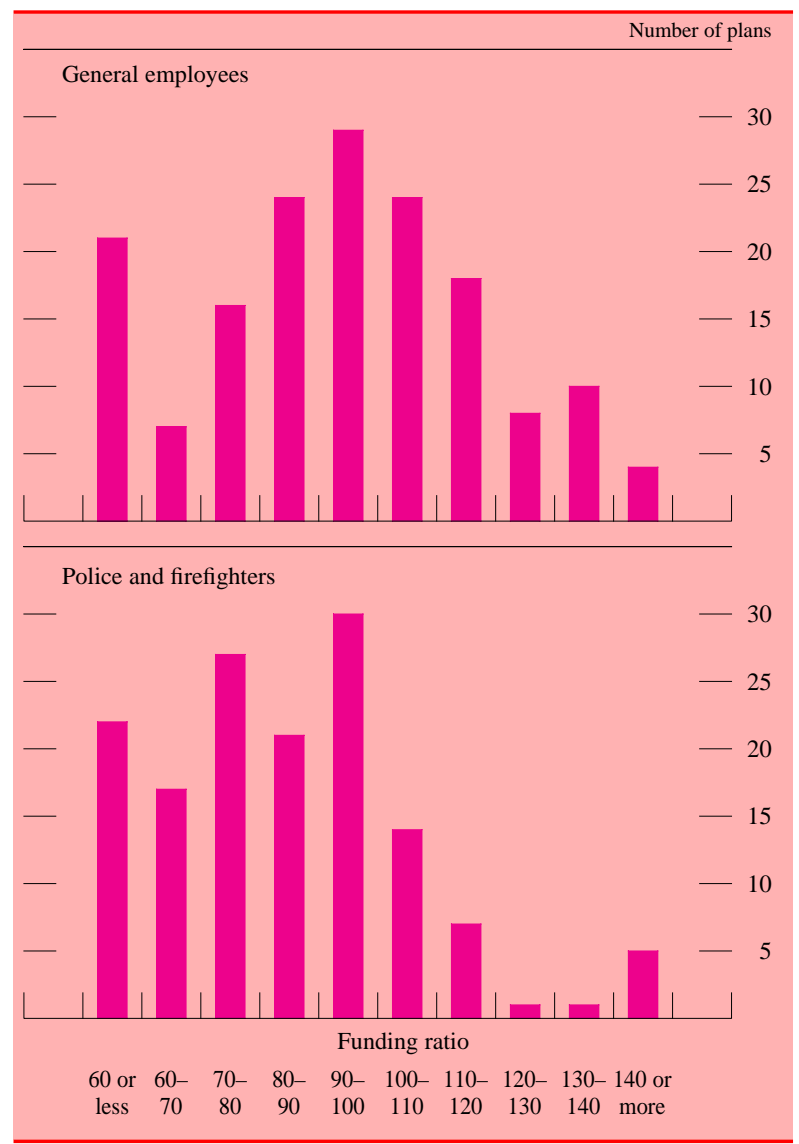

NoTE. The funding ratio is the ratio of plan assets to the actuarial accrued liability.

Source. Public Pension Coordinating Council, Survey of State and Local Government Employee Retirement Systems.
Clearly, problems exist for many state and local retirement systems, and some governments will find pension fund requirements a source of financial strain in the years ahead. However, although data are not yet available, the stock market boom of 1995 appears to have raised the assets of pension funds considerably and probably helped improve funding ratios for many state and local pension plans.

\section{SUMMARY}

Some states have only recently pulled out of the period of fiscal distress that characterized much of the early 1990s, and many cities, counties, and school districts are still wrestling to balance their budgets. In addition, tax burdens have remained at roughly the same high levels that have prevailed for the past twenty-five years (chart 9), and some citizens appear to be calling for lower taxes and less government. Therefore, many governments may not be in a financial or political position to make up possible federal cutbacks in aid.

On balance, despite the recent rosy picture, the sector's future fiscal health is far from certain. As described, many governments are coping with underlying structural changes, particularly growing populations of prisoners, school-age children, and low-

8. State and local social insurance funds, 1973-95

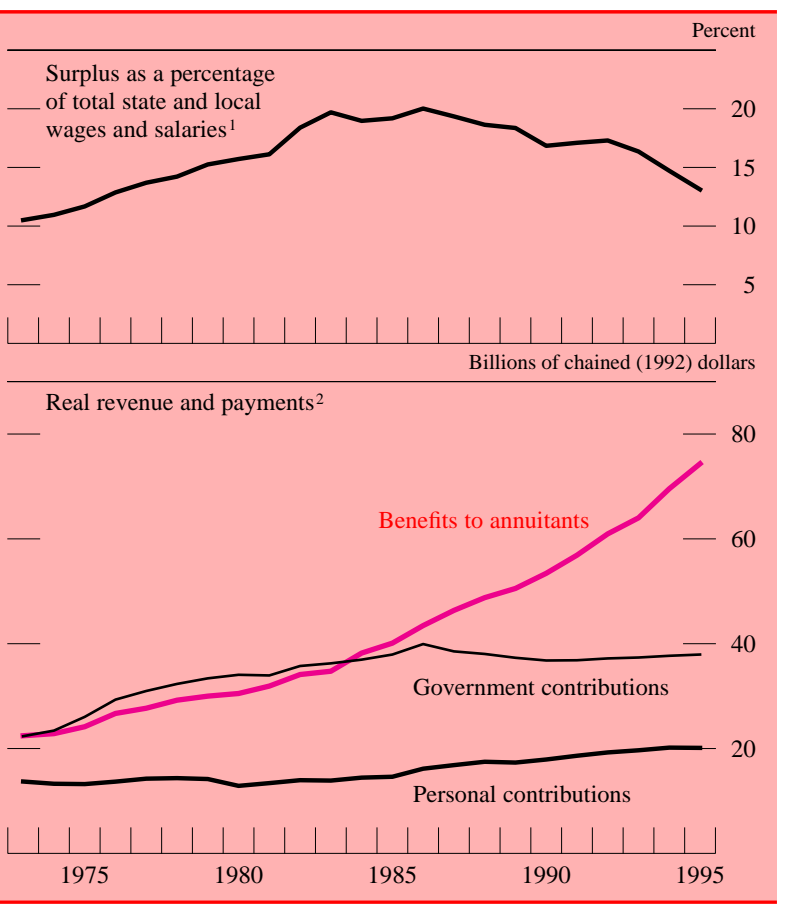

Note. Data are annual and on a NIPA basis.

1. Data for 1995 are averages of the first three quarters.

2. Deflated by the personal consumption expenditures deflator. 
income individuals in need of health care. In addition, some governments will need to add to pension funds in the years ahead to bring them to full funding.

Many governments may not be prepared if the economy weakens or if federal aid is cut. Reductions in federal grants have been under consideration for

9. State and local tax revenue as a percentage of nominal GDP, 1959-95

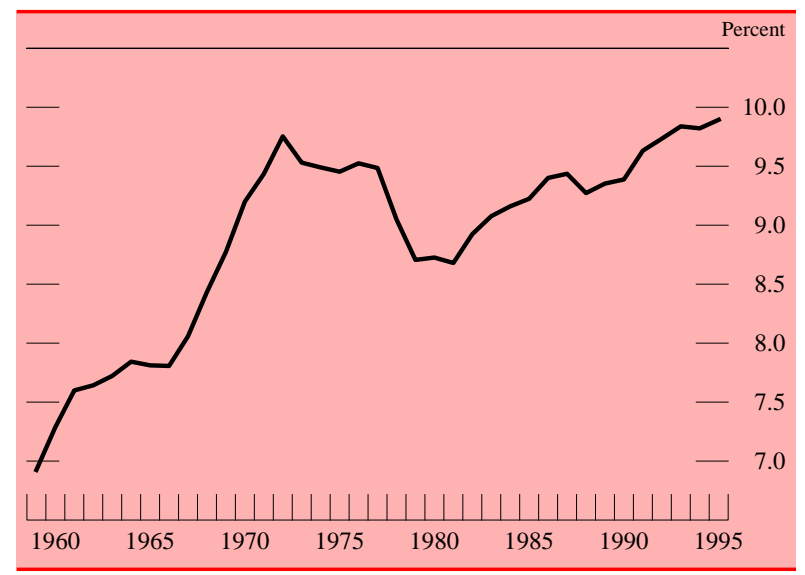

NotE. Data are annual and on a NIPA basis; the figure for 1995 is through Q3. some time, and the current impasse in Washington is creating uncertainty for state and local budget planners. Many state and local officials are concerned; however, most have still not developed specific coping strategies, and most state legislatures have not taken any formal action. Rather, planning has centered on fiscal analysis, data collection, and issue monitoring. Some governments have established interagency review committees, but quite a few have adopted a wait-and-see approach. In addition, some private groups, such as charitable organizations and business groups, have developed proposals.

Another important factor contributing to the uncertain future for the state and local sector is the direction of aggregate economic activity. Most forecasters are calling for continued growth in 1996 and 1997, perhaps at a somewhat slower pace than in the previous two years. Generally, state and local planners incorporate those forecasts into their own revenue projections. As always, unexpected weakness in economic growth could upset state and local fiscal positions. Given the uncertainties on the receipt side and continuing demand pressures, state and local governments may have to work hard to maintain program goals and keep their budgets in balance. 